\title{
Acute and sublethal effects of cadmium on ingestion, egg production and life-cycle development in the copepod Acartia tonsa
}

\author{
Kaisa Toudal \& Hans Ulrik Riisgård \\ Institute of Biology, Odense University, Campusvej 55, DK-5230 Odense M, Denmark
}

\begin{abstract}
The acute toxicity of cadmium (expressed as $96-\mathrm{h} \mathrm{LC}_{50}$ ) to the suspension-feeding copepod Acartia tonsa was highly influenced by temperature. The $\mathrm{LC}_{50}$-value was $151 \mathrm{ppb} \mathrm{Cd}$ at $13^{\circ} \mathrm{C}$, but only $29 \mathrm{ppb} \mathrm{Cd}$ at $21^{\circ} \mathrm{C}$. Salinity influenced the toxicity of cadmium. At $40 \mathrm{ppb} \mathrm{Cd}$ the clearance of algal cells (Rhodomonas baltica) was reduced at 9 and $17 \% \mathrm{~S}$, but not at $25 \% \mathrm{~S}$. There was a tendency to reduction of both algal cell ingestion and egg production at cadmium concentrations above $10 \mathrm{ppb}$. and the reduction was significant above $30 \mathrm{ppb}$. The development of copepodites and adults was influenced by both salinity $(9,17$ and $25 \% \mathrm{~S})$ and cadmium $(5,10$ and $40 \mathrm{ppb})$. The general tendency was increasingly longer developmental time at higher salinities and higher cadmium concentrations. The quickest development took place at $17 \%$ S and no cadmium which was probably a consequence of genetic adaptation to intermediate salinity. The slowest development was observed at $25 \% \mathrm{~S}$ and $40 \mathrm{ppb} \mathrm{Cd}$ where the cephalothoracic length in adult copepods was significantly reduced. Adult fertilized egg-producing females developed under all experimental conditions, and it is concluded that the 96-h $\mathrm{LC}_{50}$ values were close to the higher sublethal concentrations of $\mathrm{Cd}$ which reduced ingestion, egg production and developmental time, but allowed the copepod to accomplish an entire life-cycle.
\end{abstract}

\section{INTRODUCTION}

It has often been stressed that toxicological effect studies on pollutants should not deal only with acute toxic effects (measured as e.g. $96-\mathrm{h} \mathrm{LC}_{50}$ ). Such studies should be replaced or complemented by studies of sublethal effects on bioenergetic parameters (ingestion, respiration, growth etc.) in adults as well as in younger more sensitive developmental stages, in order to unveil latent long-term effects of pollutants at low concentrations (e.g. Rosenberg \& Costlow 1976, Johns $\&$ Miller 1982).

Copepods are important links in marine food chains, and their ubiquitous distribution and small size suggest them as a choice for bioassay organisms in pollution studies. The egg production rate of copepods has been found to be a sensitive short-term indicator of sublethal effects with obvious ecological significance, although limited to adults (Reeve et al. 1977). The importance of life-cycle toxicity tests to determine the effects of pollutants has been emphasized by Nimmo et al. (1977). Hitherto, no comparative studies on $\mathrm{LC}_{50}$, sublethal effects on egg production, development, and growth during the life-cycle have been performed on marine copepods.

Since the late 1960 's increasing interest has been devoted to cadmium as an environmental contaminant, but studies of its effects on marine organisms are more recent (Møhlenberg \& Jensen 1980). In the present work the $\mathrm{LC}_{50}$ and sublethal effects of cadmium have been studied in a marine suspension-feeding copepod, Acartia tonsa, in relation to ingestion, egg production and life-cycle development.

\section{MATERIALS AND METHODS}

The experiments were conducted at the Biological Station at Bøgebjerg, Funen, Denmark. Offspring of copepods originally transmitted as eggs from a laboratory culture of Acartia tonsa grown at the Danish Institute for Fisheries and Marine Research were used in the experiments. As egg production in A. tonsa is high and constant only during the first few weeks after maturation (Parrish \& Wilson 1978), fertilized females that had matured within the previous 1 to $2 \mathrm{wk}$ were 
employed. Copepods to be used in the experiments were reared at known time intervals ( 1 wk) by transferring 15000 to 40000 eggs sucked from the bottom of a $100 \mathrm{l}$ cultivation tank with all developmental stages of copepods to one of four $100 \mathrm{l}$ cultivation tanks where hatching and subsequent growth and maturation took place. The copepods were reared at 10 to $18^{\circ} \mathrm{C}$ in 12 to $20 \%$ S seawater to which phytoplankton algae Rhodomonas baltica were added 5 times a week to maintain a mean concentration of about 15000 algal cells $\mathrm{ml}^{-1}$. The cultivation tanks were slightly aerated to prevent sedimentation of the algae. Fertilized females (i.e. carrying a spermatophore) from 3 to 4 wk old cultures were sorted out under a microscope and used for experiments.

Rhodomonas baltica (about $6 \mu \mathrm{m}$ in diameter) was cultivated at $18^{\circ} \mathrm{C}$ and continuous dim light (about $130 \mu \mathrm{E} \mathrm{m}^{-2} \mathrm{~s}^{-1}$ ) in $8 \mathrm{l}$ semibatch-cultures with a concentration of about $10^{6}$ algal cells $\mathrm{ml}^{-1}$ ensured by a dilution rate of $25 \% \mathrm{~d}^{-1}$. The culture medium was autoclaved natural seawater (15 to $20 \%$ S) enriched with nutrients, but without EDTA or other chelators.

Volume of water cleared of algal cells per unit time (i.e. clearance) was measured by incubating 15 to 20 fertilized copepods in $550 \mathrm{ml}$ screw-cap glass jars containing a suspension of Rhodomonas baltica at the desired concentration. By measuring the reduction in algal cell concentration the clearance $(F)$ was calculated according to the following equation of Kiørboe et al. (1982): $F=V /(n \times t) \times \ln (C 1 \times C 2 k) /(C 2 \times C 1 k)$, where $\mathrm{V}=$ volume of glass jar; $\mathrm{n}=$ number of copepods; $\mathrm{t}=$ experimental time; $\mathrm{C} 1$ and $\mathrm{C} 2=$ algal concentration at times 0 and $\mathrm{t}$, respectively; and $\mathrm{C} 1 \mathrm{k}$ and $\mathrm{C} 2 \mathrm{k}=$ algal concentration in controls. To each glass jar was added $0.5 \mathrm{ml}$ concentrated algal growth medium to prevent nutrient limitation of algal growth during the incubation time, during which the jars were fixed on a rotating wheel $(1 \mathrm{rpm})$. One $\mathrm{d}$ before the experimental measurements were made the copepods were acclimated to the desired algal concentration in the glass jars. At time 0 and $24 \mathrm{~h}$, or every $24 \mathrm{~h}$ during incubation periods of $3 \mathrm{~d}$ when egg production was measured, samples were withdrawn for measurement of algal cell concentration on an Elzone $80 \mathrm{XY}$ electronic particle counting system fitted with a $76 \mu \mathrm{m}$ orifice tube. The concentration of algae relative to controls without copepods decreased 20 to $50 \%$ during the incubation periods. The mortality was less than $10 \%$ during incubation periods of $3 \mathrm{~d}$.

Food ingestion rate (I) was estimated according to Kiørboe et al. (1982) as the average algal cell concentration $(\mathrm{C})$ times clearance $(\mathrm{F}): \mathrm{I}=\mathrm{C} \times \mathrm{F}$; where $\mathrm{C}=$ (C2-C1)/ln(C2/C1).

Copepod eggs were separated for counting by gently pouring the contents of the glass jars first through a
$180 \mu \mathrm{m}$ mesh sive (which retains the copepods) and then through a $40 \mu \mathrm{m}$ mesh sieve, which retains the eggs to be counted under a microscope after being dyed with Lugol's iodine solution.

The effect of cadmium on clearance, ingestion and egg production at different salinities and temperatures was studied by adding cadmium (as $\mathrm{CdCl}_{2}$ ) to the experimental jars with fertilized copepods and $2 \times 10^{4}$ algal cells $\mathrm{ml}^{-1}$. Each experiment run at a desired cadmium concentration was performed with 3 replicate glass jars with added cadmium and 3 control jars without additional cadmium. The significance of the difference between copepods exposed to cadmium and controls was tested by a t-test (Zar 1974).

Dry weight $(W, \mu \mathrm{g})$ of female copepods was estimated from measurement of the cephalothoracic length $(\mathrm{L}, \mathrm{mm})$ in representative specimens using the relation $W=13.4 \mathrm{~L}^{3}$ (Kiørboe et al. 1985). Mean cephalothorax length was $0.87 \pm 0.02 \mathrm{~mm}$ corresponding to an average dry weight of $8.82 \mu \mathrm{g}$. Assuming a carbon content of $40 \%$ of body dry weight (Parsons et al. 1977), a female Acartia tonsa had a content of $3.5 \mu \mathrm{g}$ C. Carbon content in algal cells and copepod eggs was assumed to be the same as found by Kiørboe et al. (1985), i.e. Rhodomonas baltica $=36.7 \mathrm{pg} \mathrm{C} \mathrm{cell}{ }^{-1} ; A$. tonsa $=45.7 \mathrm{ng} \mathrm{C} \mathrm{egg}^{-1}$.

In order to determine the sublethal concentrations of cadmium to be used in the experiments, the concentration of cadmium that kills $50 \%$ of a Acartia tonsa population within $96 \mathrm{~h}$ (i.e. $\mathrm{LC}_{50}$ ) was found at different salinities and temperatures. The $\mathrm{LC}_{50}$ experiments were performed by transferring about 20 adult copepods to glass beakers with $250 \mathrm{ml}$ seawater with added cadmium in known concentrations. The copepods were not fed. Dead individuals were counted after $96 \mathrm{~h}$ to establish the relation between percent mortality and concentration of cadmium, from which the $\mathrm{LC}_{50}$ value could be estimated by means of a probit analysis (Finney 1971).

The sublethal effects of cadmium on growth and developmental time during all ontogenetic stages from hatching to adult fertile stage was studied at 3 salinities $(9,17$ and $25 \%$ S) obtained by adjusting the salinity of $16 \% \mathrm{~S}$ natural seawater with $\mathrm{NaCl}$ or demineralized water. Approximately 700 Acartia tonsa eggs were transferred to aquaria holding 181 seawater and containing $2 \times 10^{4}$ Rhodomonas baltica cells $\mathrm{ml}^{-1}$ and sublethal concentrations of cadmium. The algal concentration was adjusted every second day, and the water changed once every week. Representative samples of the different copepod stages were taken at different times during development by means of a $40 \mathrm{um}$ mesh sieve to be able to establish the relation between developmental stage and time under the different environmental conditions. At the end of the 
experiment the cephalothoracic length of representative specimens from each aquarium was measured. An analysis of variance was employed to test the significance of the difference between treatments. If significant differences $(p=0.05)$ were found, a NewmanKeuls multiple range test was used to determine where the differences occurred (Zar 1974).

\section{RESULTS}

Clearance, ingestion and egg production as a function of algal concentration expressed in carbon units are shown in Fig. 1. The few data on clearance at the lower algal concentrations makes it problematic to fit a
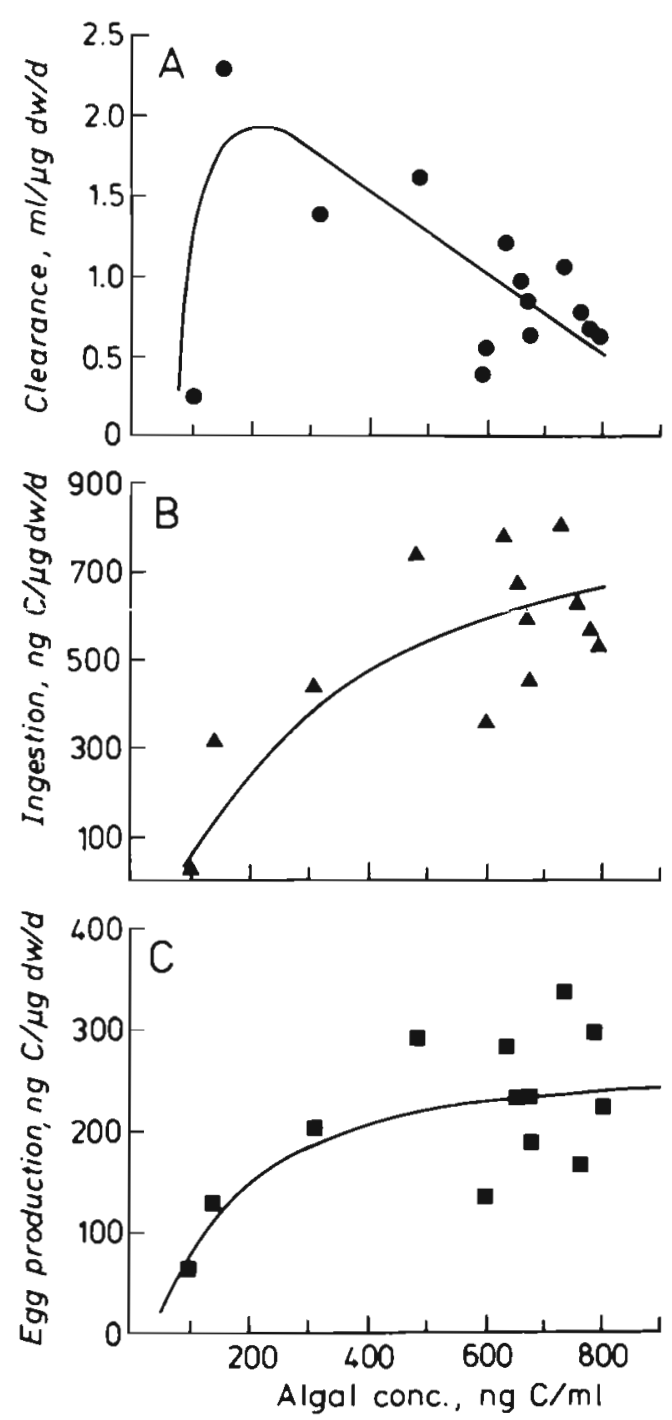

Fig. 1. Acartia tonsa. Clearance, ingestion (I) and egg production (G) as a function of algal concentration (C). Each point represents the average of 3 replicates. The lines shown are: (A) fitted by eye, (B) $I=970 \times e^{-288 / C}\left(r^{2}=0.78\right)$, (C) $G=$ $287 \times e^{-131 / C}\left(r^{2}=0.65\right)$ curve, but apparently the clearance had a maximum at an algal concentration of about $150 \mathrm{ng} \mathrm{C} \mathrm{ml} \mathrm{Cl}^{-1}$. Ingestion increased sigmoidally with algal concentration and approached a plateau at about $700 \mathrm{ng} \mathrm{C}(\mu \mathrm{g} \mathrm{dw})^{-1}$ $\mathrm{d}^{-1}$, equivalent to $175 \%$ body carbon per day. Egg production varied linearly with ingestion rate (Fig. 2) and the slope of the regression line indicates a conversion efficiency of $32 \%$ for ingested carbon to eggcarbon. Based on these findings it was decided to carry

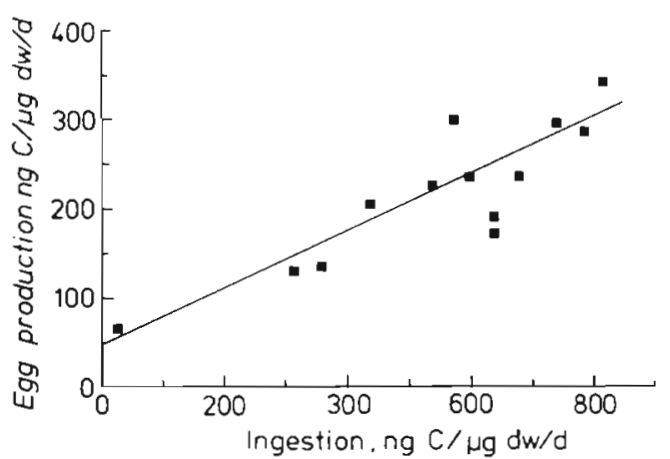

Fig. 2. Acartia tonsa. Egg production (G) as a function of ingestion rate (I). Data from Fig. 1. Regression line is: $G=$ $46+0.32 \times I\left(r^{2}=0.80\right)$

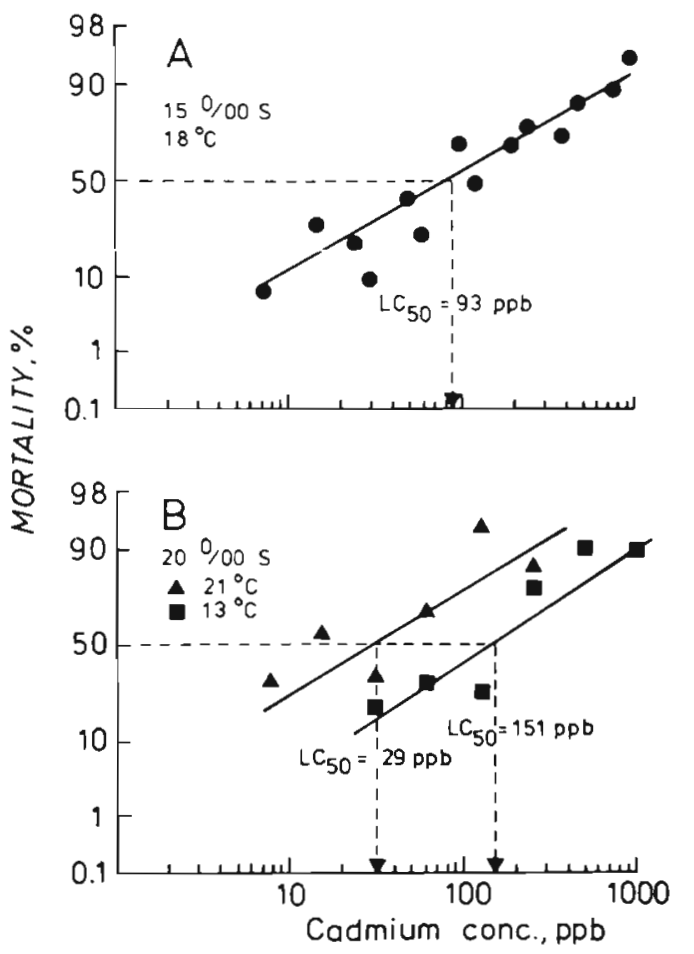

Fig. 3. Acartia tonsa. Mortality of copepods (expressed as percentage dead on a probit scale) as a function of cadmium concentration at different salinities and temperatures. The regression lines are shown as well as the estimated $50 \%$ mortality after $96 \mathrm{~h}$ exposure (i.e. $\mathrm{LC}_{50}$ ). The $\mathrm{LC}_{50}$ values, with $95 \%$ confidence limits shown in parentheses were: (A) 93 (82-106) ppb Cd; (B) $\left(21^{\circ} \mathrm{C}\right) 29(23-37)$ and $\left(13^{\circ} \mathrm{C}\right) 151$ (120-191) ppb Cd 
out the cadmium effect studies at an algal concentration of $700 \mathrm{ng} \mathrm{C} \mathrm{ml}^{-1}$, equivalent to $1.9 \times 10^{4}$ algal cells $\mathrm{ml}^{-1}$.

The acute toxic effect of cadmium on Acartia tonsa was influenced both by temperature and salinity (Fig. 3). The $\mathrm{LC}_{50}$ value was $151 \mathrm{ppb} \mathrm{Cd}$ at $13^{\circ} \mathrm{C}$, but only $29 \mathrm{ppb} \mathrm{Cd}$ at $21^{\circ} \mathrm{C}$. From the $\mathrm{LC}_{50}$ values it was decided to run sublethal effect experiments at cadmium concentrations of 10 to $50 \mathrm{ppb}$.

The effects of $40 \mathrm{ppb}$ cadmium on exponential reduction in algal cell concentration and clearance at different salinities are shown in Fig. $4 \& 5$. At the lower salinities ( 9 and $17 \% \mathrm{~S}$ ) reduced clearance could be noticed at $40 \mathrm{ppbCd}$ whereas no effect was seen at $25 \%$ S.

The effect of cadmium on ingestion and egg production is shown in Fig. 6. There was a tendency for reduction in both of these parameters at cadmium concentrations above $10 \mathrm{ppb}$, but the reduction was significant above $30 \mathrm{ppb}(\mathrm{p}<0.05)$. The conversion efficiency for ingested carbon to egg-carbon (i.e. the gross growth efficiency, since growth in adult females

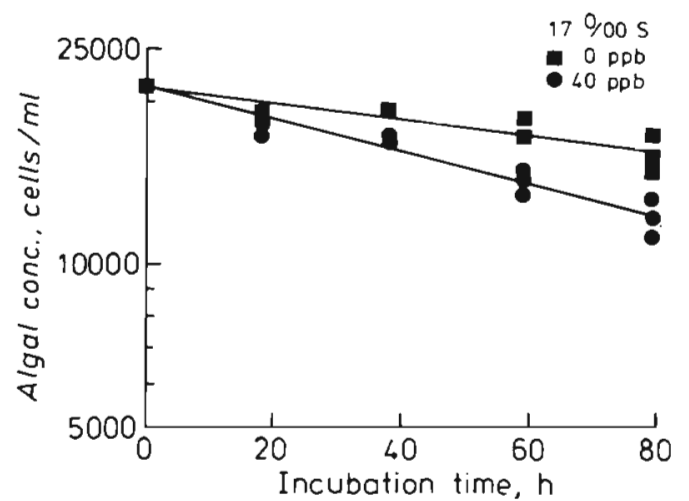

Fig. 4. Acartia tonsa. Exponential reduction in algal cell concentration in glass jars with copepods as a function of time in experiments run at $18^{\circ} \mathrm{C}$ with 0 and $40 \mathrm{ppb} \mathrm{Cd}$ added to the water $(17 \%$ S). Regression lines are shown

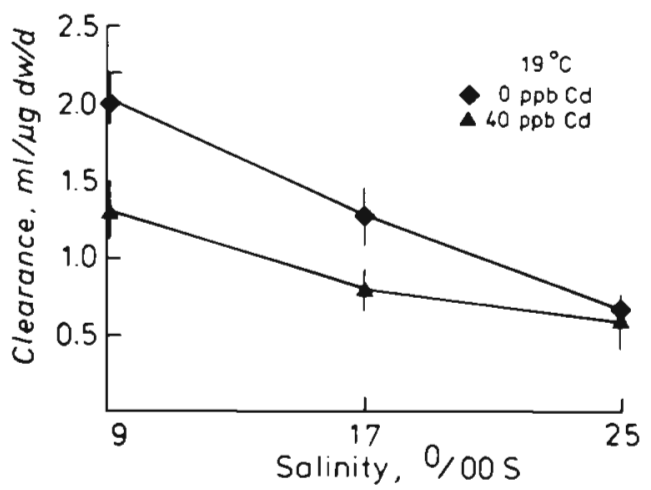

Fig. 5. Acartia tonsa. Effect of $40 \mathrm{ppb}$ cadmium on clearance measured during the first day of incubation of copepods in experiments run at different salinities

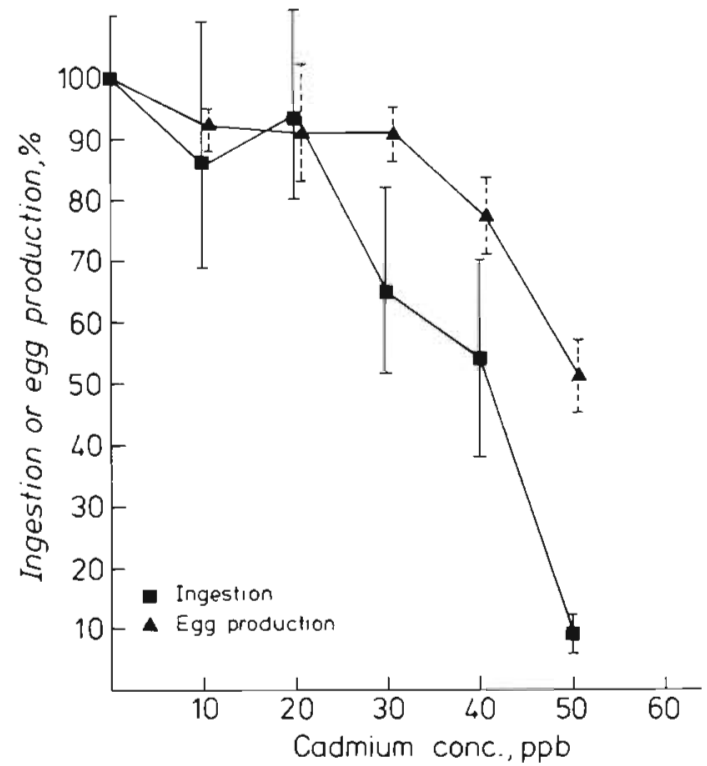

Fig. 6. Acartia tonsa. Ingestion and egg production (expressed as percentage of controls) as a function of cadmium concentration in experiments performed at $17 \% \mathrm{~S}$ and $18^{\circ} \mathrm{C}$. Each point represents the average of 3 replicates. Vertical lines represent the range calculated on the basis of the mean values of Cd-exposed copepods \pm SEM in relation to mean values of control $\pm \mathrm{SEM}$

is mainly in the form of egg production) was apparently increasing with increasing cadmium concentration (Table 1).

The development of copepodites and adults was influenced by both salinity and cadmium (Fig. 7). The general tendency was longer developmental time at high salinities and high cadmium concentrations. The quickest development took place at $17 \%$ S and no cadmium. The slowest development was observed at $25 \% \mathrm{~S}$ and $40 \mathrm{ppb} \mathrm{Cd}$. The cephalothoracic length in adult copepods grown under the latter conditions was also significantly reduced $(\mathrm{p}<0.05$ ) (Table 2 ). Adult fertilized and egg-producing females developed under all experimental conditions, but the number of eggs laid in $40 \mathrm{ppb} \mathrm{Cd}$ experiments performed at 17 and $25 \%$ S were about $25 \%$ reduced. The number of eggs hatched in all experiments with added $40 \mathrm{ppb}$ Cd were about $10 \%$ reduced compared to controls.

\section{DISCUSSION}

The clearances measured in the present work (Fig. 1A) are in fairly good agreement with Kiørboe et al. (1985) who found that the clearance in Acartia tonsa peaked at a food concentration of about $150 \mathrm{ng} \mathrm{C} \mathrm{ml}{ }^{-1}$ and decreased at both higher and lower algal concentration levels. Also ingestion, egg production (Fig. 1B, 
Table 1. Acartia tonsa. Conversion efficiencies for ingested carbon (I) to egg-carbon (G) in copepods exposed to different cadmium concentrations. Mean values \pm SEM of 3 replicates in cadmium experiments and 15 replicates of controls

\begin{tabular}{|cc|}
\hline Cd. conc. (ppb) & G/I \\
\hline 0 & $0.40 \pm 0.02$ \\
10 & $0.45 \pm 0.02$ \\
20 & $0.42 \pm 0.03$ \\
30 & $0.51 \pm 0.03$ \\
40 & $0.61 \pm 0.06$ \\
50 & $2.06 \pm 0.19$ \\
\hline
\end{tabular}
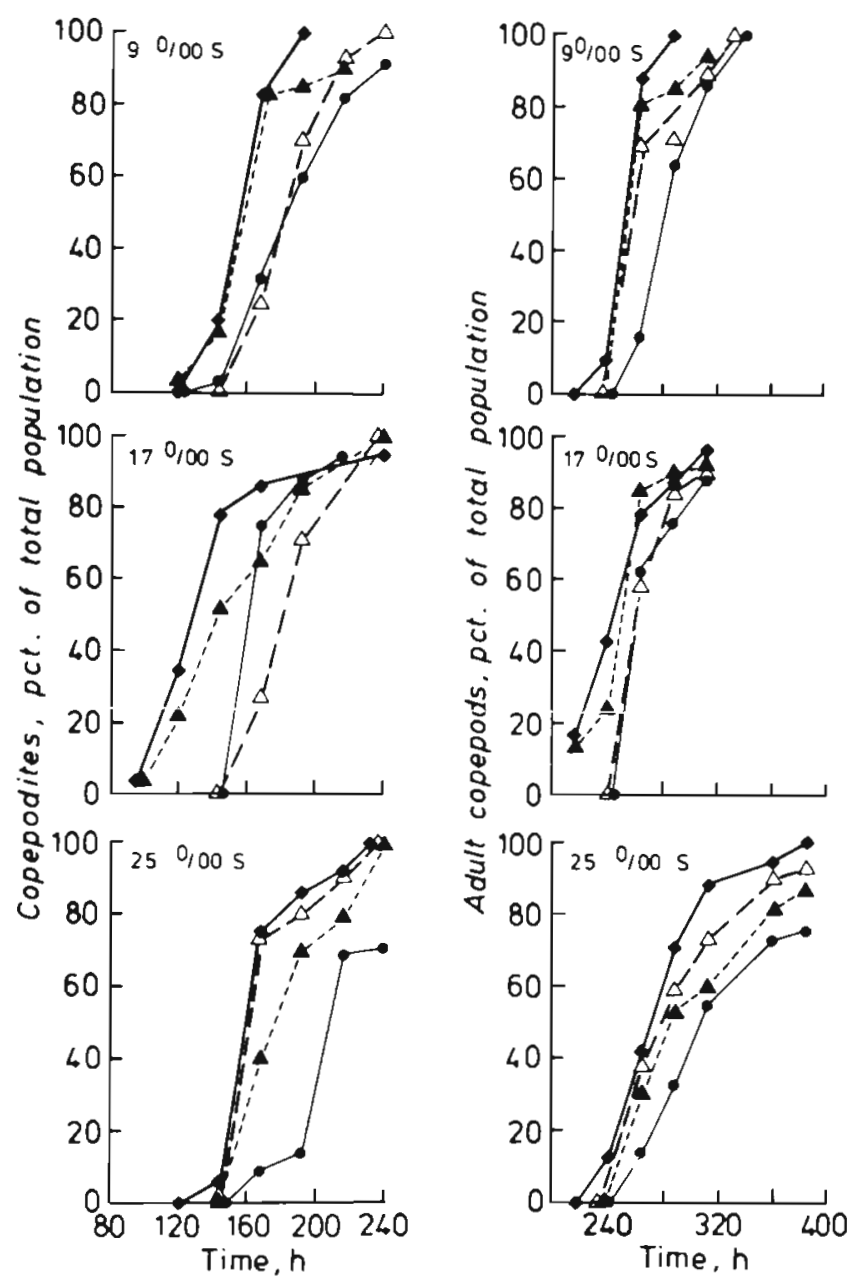

Fig. 7. Acartia tonsa. Development of copepodites (CV) and adults expressed as percentage of the total population as a function of time from transfer of eggs to growth aquaria in experiments performed at $18^{\circ} \mathrm{C}$ and different salinities and cadmium concentrations. $(\bullet)$ Controls; $(\Delta) 5 \mathrm{ppb} \mathrm{Cd}$; (^) $10 \mathrm{ppb} \mathrm{Cd}$; (•) $40 \mathrm{ppb} \mathrm{Cd}$

C) and conversion efficiencies for ingested carbon to egg-carbon (Fig. 2) in the present work are in good agreement with Kiørboe et al. (1985) who found for example that the ingestion rate was equivalent to
$180 \%$ of body carbon per day (compared to $175 \%$ in this work) and that ingested carbon was converted into egg-carbon with an efficiency of $36 \%$ (compared to $32 \%$ [Fig. 2] and $40 \%$ [Table 1] in this work).

Table 2. Acartia tonsa. Cephalothoracic length ( $\mathrm{mm}$ ) in adult copepods grown at $18^{\circ} \mathrm{C}$ and different salinities and cadmium concentrations (see also Fig. 7). Values are the mean of 12 measurements \pm SEM

\begin{tabular}{|cccc|}
\hline $\begin{array}{c}\text { Cd conc. } \\
\text { (ppb) }\end{array}$ & $9 \%$ & $17 \% 0$ & $25 \%$ \\
\hline 0 & $0.89 \pm 0.01$ & $0.89 \pm 0.01$ & $0.86 \pm 0.01$ \\
5 & - & - & $0.86 \pm 0.01$ \\
10 & $0.88 \pm 0.01$ & $0.89 \pm 0.01$ & $0.88 \pm 0.01$ \\
40 & $0.90 \pm 0.01$ & $0.86 \pm 0.01$ & $0.81 \pm 0.01$ \\
\hline
\end{tabular}

The time necessary for egg production to come into equilibrium with ingestion rate was measured to be about $1 \mathrm{~d}$ by Kiørboe et al. (1985). This explains the phenomenon of apparently increasing conversion efficiencies at increasing cadmium concentrations (Table 1): when ingestion decreases due to the effect of cadmium this gives rise to apparently higher conversion efficiencies because egg production varies with ingestion rate with some time lag. This phenomenon also explains the less pronounced effects of cadmium on egg production compared to the effects on ingestion rate (Fig. 6). The reduced egg production in cadmiumexposed copepods seems to be a consequence of reduced ingestion rate (Fig. 4 \& 5).

The acute toxicity of cadmium (expressed as 96-h $\mathrm{LC}_{50}$ ) on Acartia tonsa was influenced by both salinity and temperature. At $15 \% \mathrm{~S}\left(18^{\circ} \mathrm{C}\right)$ the $\mathrm{LC}_{50}$ value was $93 \mathrm{ppb}$ (Fig. 3A), but at $20 \%$ S LC 50 values were $151 \mathrm{ppb}$ and $29 \mathrm{ppb}$ at 13 and $21^{\circ} \mathrm{C}$ respectively (Fig. 3B). The $\mathrm{LC}_{50}$ values may be compared with 96 -h $\mathrm{LC}_{50}$ values of 90 to $337 \mathrm{ppb} \mathrm{Cd}\left(10 \% \mathrm{~S}, 20^{\circ} \mathrm{C}\right)$ and $122 \mathrm{ppb} \mathrm{Cd}\left(30 \% \mathrm{~S}, 20^{\circ} \mathrm{C}\right)$ found in $A$. tonsa by Sosnowski \& Gentile (1978), and $15.5 \mathrm{ppb} \mathrm{Cd}$ (15 to $23 \% \mathrm{~S}, 20$ to $28^{\circ} \mathrm{C}$ ) in Mysidopsis bahia by Nimmo et al. (1977).

Salinity also influenced the effects of cadmium on clearance (Fig. 5). At $40 \mathrm{ppb} \mathrm{Cd}$ clearance was reduced at 9 and $17 \%$ S, but not at $25 \%$ S. The protective effect of high salinity is probably attributable to chloride ion complexation of cadmium. Similarly, a reduced mortality of cadmium in shrimps at higher salinities was correlated with a decreasing concentration of free (toxic) cadmium ions due to cadmium complexation by chloride ions (Sunda et al. 1978). According to Long \& Angino (1977) the chloro-complexes account for an increasing fraction of dissolved forms when salinity increases. Free cadmium ions thus gradually decrease 
reaching only about $2 \%$ of dissolved forms in $35 \% \mathrm{~S}$ seawater. If cadmium is taken up by the same mechanisms as calcium, the higher toxicity of cadmium noted at the lower salinities may also partly be due to a higher accumulation rate of cadmium at lower salinities when the calcium concentration is low and uptake accelerated in order to meet calcium demand (Wright 1978).

The higher clearance (Fig. 5) and faster development at intermediate salinities (Fig. 7) is probably a consequence of genetic adaptation to low salinity. The Acartia tonsa used was originally isolated from the brackish Øresund, Denmark. This makes it difficult to discriminate between the toxic effects of cadmium in relation to its degree of complexation by chloride ions at different salinities and the effects of different salinities. From the present findings it may, however, be concluded that the acute toxic concentrations of cadmium (expressed as $\mathrm{LC}_{50}$ values) on $A$. tonsa are quite close to the higher sublethal concentrations which reduce ingestion, egg production and developmental time, but allow the copepod to accomplish an entire life-cycle. The cadmium concentrations used in our experiments may be compared to a mean of $0.025 \mathrm{ppb} \mathrm{Cd}$ in the Danish Sounds and the Kattegat (Magnusson \& Rasmussen 1982).

Acknowledgements. Thanks are due to Mrs Lone Morgen for technical assistance and to Drs. Thomas Kiørboe and Flemming Mohlenberg for critically reading the manuscript. This work was supported by a grant from the Danish Natural Science Research Council

\section{LITERATURE CITED}

Finney, D. J. (1971). Probit analysis. Cambridge Univ. Press, Cambridge

Johns, M. D., Miller, D. C. (1982). The use of bioenergetics to investigate the mechanisms of pollutant toxicity in crustacean larvae. In: Vernberg, W. B., Calabrese, A., Thurberg, F. P., Vernberg, F. J. (ed.) Physiological mechanisms of marine pollutant toxicity. Academic Press, London, p. 261-288

Kiørboe, T., Møhlenberg, F., Nicolajsen, H. (1982). Ingestion rate and gut clearance in the planktonic copepod Centropages typicus (Liljeborg) in relation to food concentration and temperature. Ophelia 21 (2): 181-194

Kiørboe, T., Møhlenberg, F., Hamburger, K. (1985). Bioenergetics of the planktonic copepod Acartia tonsa: relation between feeding, egg production and respiration, and composition of specific dynamic action. Mar. Ecol. Prog. Ser. 26: 85-97

Long, D. T., Angino, E. E. (1977). Chemical speciation of Cd, $\mathrm{Cu}, \mathrm{Pb}$, and $\mathrm{Zn}$ in mixed freshwater, seawater and brine solution. Geochim. Cosmochim. Acta 41: 1183-1191

Magnusson, B., Rasmussen, L. (1982). Trace metal levels in coastal sea water. Investigation of Danish waters. Mar. Pollut. Bull 13: 81-84

Møhlenberg, F., Jensen, A. (1980). The ecotoxicology of cadmium in fresh and sea water and water pollution with cadmium in Denmark. The National Agency of Environmental Protection, Copenhagen, Denmark

Nimmo, D. R., Bahner, L. H., Rigby, R. A., Sheppard, J. M., Wilson, A. J., Jr. (1977). Mysidopsis bahia: an estuarine species suitable for life-cycle toxicity tests to determine the effects of a pollutant. In: Mayer, F. L., Hamelink, J. L. (ed.) Aquatic Toxicol. Hazard Eval. ASTM STP 634. American Society for Testing Materials, p. 109-116

Parrish, K. K., Wilson, D. F. (1978). Fecundity studies on Acartia tonsa (Copepoda: Calanoida) in standardized culture. Mar. Biol. 46: 65-81

Parsons, T. R., Takahashi, M., Hargrave, B. (1977). Biological oceanographic processes, 2nd edn. Pergamon Press, Oxford

Reeve, M. R., Walter, M. A., Darcy, K., Ikeda, T. (1977). Evaluation of potential indicators of sub-lethal toxic stress on marine zooplankton (feeding, fecundity, respiration, and excretion): controlled ecosystem pollution experiment. Bull. mar. Sci. 27 (1): 105-113

Rosenberg, R., Costlow, J. D., Jr. (1976). Synergistic effects of cadmium and salinity combined with constant and cycling temperatures on the larval development of two estuarine crab species. Mar. Biol. 38: 291-303

Sosnowski, S. L., Gentile, J. H. (1978). Toxicological comparison of natural and cultured populations of Acartia tonsa to cadmium, copper, and mercury. J. Fish. Res. Bd Can. 35: 1366-1369

Sunda, W. G., Engel, D. W., Thuotte, R. M. (1978). Effect of chemical speciation on toxicity of cadmium to grass shrimp, Palaemonetes pugio: importance of free cadmium ion. Environ. Sci. Technol. 12 (4): 409-413

Wright, D. A. (1978). Heavy metal accumulation by aquatic invertebrates. Appl. Biol. 3: 311-394

Zar, J. H. (1974). Biostatistical analysis. Prentice Hall, Englewood Cliffs, New Jersey 